\title{
Recent Trends and Impacts of Fisheries Exploitation on Mediterranean Stocks and Ecosystems
}

\author{
Francesco Colloca ${ }^{1,2 *}$, Giuseppe Scarcella ${ }^{3}$ and Simone Libralato ${ }^{4}$ \\ ${ }^{1}$ Istituto per l'Ambiente Marino Costiero, Consiglio Nazionale delle Ricerche, Mazara del Vallo, Italy, ${ }^{2}$ Dipartimento di Biologia \\ e Biotecnologie 'Charles Darwin', Università degli Studi di Roma La Sapienza, Rome, Italy, ${ }^{3}$ Istituto di Scienze Marine, \\ Consiglio Nazionale delle Ricerche, Ancona, Italy, ${ }^{4}$ stituto Nazionale di Oceanografia e di Geofisica Sperimentale - OGS, \\ Trieste, Italy
}

\section{OPEN ACCESS}

Edited by:

Rachel Gjelsvik Tiller,

SINTEF, Norway

Reviewed by:

Sanja Matic-Skoko

Institute of Oceanography and

Fisheries, Croatia

Dimitrios K. Moutopoulos, Technological Educational Institute of

Messolonghi, Greece

*Correspondence:

Francesco Colloca

francesco.colloca@iamc.cnr.it

Specialty section:

This article was submitted to Marine Fisheries, Aquaculture and

Living Resources,

a section of the journal

Frontiers in Marine Science

Received: 17 March 2017

Accepted: 18 July 2017

Published: 14 August 2017

Citation:

Colloca F, Scarcella G and Libralato S (2017) Recent Trends and Impacts of

Fisheries Exploitation on

Mediterranean Stocks and

Ecosystems. Front. Mar. Sci. 4:244.

doi: 10.3389/fmars.2017.00244
This review focuses on the recent data on Mediterranean fishing fleets and landings, results from stock assessments and ecosystem models to provide an overview of the multiple impacts of fishing exploitation in the different Mediterranean geographical sub-areas (GSAs). A fleet of about 73,000 vessels is widespread along the Mediterranean coasts. Artisanal activities are predominant in South Mediterranean and in the eastern basin, while trawling features GSAs in the western basin and the Adriatic Sea. The overall landings of fish, crustaceans and cephalopods, after peaking during mid 90s at about one million tons, declined at about 700,000 tons in 2013. However, while landings are declining in EU countries since the 90s, in non-EU countries a decreasing trend was observed only in the last 5-10 years. The current levels of fishing effort determine a general overexploitation status of commercial stocks with more than $90 \%$ of the stock assessed out of safe biological limits. Indicators obtained from available ecosystem models were used to assess the sustainability of the fisheries. They included primary production required to sustain fisheries (PPR), mean trophic level of the catch (mTLc), the loss in secondary production index ( $\mathrm{L}$ index), and the probability of the ecosystem to be sustainably exploited ( $\left.p_{\text {sust }}\right)$. In areas exploited more sustainably (e.g., Gulf of Gabes, Eastern Ionian, and Aegean Sea) fishing pressure was characterized by either low number of vessels per unit of shelf area or the large prevalence of artisanal/small scale fisheries. Conversely, GSAs in Western Mediterranean and Adriatic showed very low ecosystem sustainability of fisheries that can be easily related with the high fishing pressure and the large proportion of overfished stocks obtained from single species assessments. We showed that the current knowledge on Mediterranean fisheries and ecosystems describes a worrisome picture where the effect of poorly regulated fisheries, in combination with the ongoing climate forcing and the rapid expansion of nonindigenous species, are rapidly changing the structure and functioning of the ecosystem with unpredictable effects on the goods and services provided. Although this would call for urgent conservation actions, the management system implemented in the region appears too slow and probably inadequate to protect biodiversity and secure fisheries resources for the future generations.

Keywords: Mediterranean, fisheries, overexploitation, ecosystem models, fisheries management 


\section{INTRODUCTION}

The Mediterranean ecosystem has a long history of human disturbance and exploitation. A growing body of knowledge and recent single species assessments are showing a general overexploitation status of commercial fish and shellfish stocks along with a rapid decline of large predators, such as sharks (Ferretti et al., 2008, 2013; Fortibuoni et al., 2010, 2016). While the impact of poorly regulated fisheries is widely documented in EU Mediterranean waters (Colloca et al., 2013; Vasilakopoulos et al., 2014), the status of fisheries and stocks in non-EU countries, where a standardized fisheries data collection system is generally not yet fully enforced, is still unclear. However, taking into consideration the recent reports of the working groups on stock assessment of the General Fisheries Commission for the Mediterranean (GFCM), it is possible to argue that also in the non-EU countries the situation might be critical (GFCM, 2016a,b).

In recent years there are also increasing evidences on the negative impacts of fishing on the Mediterranean trophic web and ecosystem. Analyses on the impact of fishing on the ecosystem, quantified through an index of Loss in secondary production (Libralato et al., 2008) resulted a general low probability of the ecosystem to be sustainably fished in the Mediterranean Sea both from models and data (Libralato et al., 2005). Moreover, the meta-analysis of Mediterranean model outputs highlighted detectable signs of impacts of fishing from several ecosystem indicators (Coll and Libralato, 2012).

The ecosystem change was so fast during the last 50 years to be directly witnessed in different Mediterranean areas by fishermen and vessel captains (Maynou et al., 2011), highlighted from analysis of landing statistics (Fortibuoni et al., 2017), and documented in several studies (Lleonart, 1993; Abelló et al., 2002; Coll et al., 2006, 2007; Libralato et al., 2008; Azzurro et al., 2011).

In addition, there is a growing concern about the damages on the benthic habitat caused by towed gears such as otter trawls, dredges, beam trawls (Pranovi et al., 2000; Smith et al., 2000; de Juan et al., 2007; De Biasi and Pacciardi, 2008; de Juan and Lleonart, 2010).

The critical situation of commercial stocks rose the concerns also for several factors than alone or in combination with fisheries are contributing to worsening the conditions of marine Mediterranean communities. Increasing body of research is showing fast spreading of new invasive species in the Mediterranean (Lejeusne et al., 2009; Galil et al., 2014; Parravicini et al., 2015) that can have indirect effects on resident communities and fisheries difficult to quantify (e.g., Libralato et al., 2015). Pollution and marine litter are having strong attention because of the several indirect and direct impacts on both stocks and fisheries (Galgani, 2015). Nutrient loads from watershed have been regulated with important changes in the last decades resulting in direct effects on marine coastal area primary productivity and exploited resources (Caddy, 2000; Fortibuoni et al., 2017). Climatic global changes are also influencing Mediterranean marine communities by changing average temperature, productivity and water alkalinity (Lazzari et al., 2012, 2014; Cossarini et al., 2015) with potentially large effects on exploited stocks (Colloca et al., 2014).
Although there is a general concern about the lack of adequate management measures to reverse the ongoing negative trends and drive Mediterranean fisheries toward a sustainable exploitation, the overall picture of the situation of fisheries and ecosystems is still rather confused.

In this review, we used multiple source of information to summarize the current knowledge on commercial demersal fisheries in European and non-European waters. Starting from a review of the fisheries trend we considered the status of commercial stocks in the different Mediterranean FAO-GFCM Geographical sub-areas (GSAs). These data were complemented with information on the outputs of main ecosystem models available in Mediterranean to produce an overview of the overall impact of fishing on the ecosystem. In this perspective, we considered also data on non-indigenous fish species and knowledge on the conservation status of Mediterranean fish from the International Union for Conservation of Nature (IUCN) assessments.

Our main goal was to provide a general overview on Mediterranean fisheries and discuss the multiple effects generated by fishing exploitation, from commercial stocks to the whole ecosystem, in relation to the challenging long-term sustainability objectives of the European Union (sensu CFP Reg. no. 1380/2013) and FAO (UN; sensu SDG 14, FAO SO2 and the Aichi Targets).

\section{MATERIALS AND METHODS}

\section{Fisheries Data}

Data available on fishing capacity, as total number of artisanal vessels using fixed gears (e.g., trammel nets, long-lines, traps, etc.), trawlers, purse-seiners, and pelagic trawlers, in each Mediterranean Geographical Sub-Areas (GSAs, Figure 1) were obtained from several sources (see Table 1). These includes technical reports of both the FAO-GFCM and the Scientific Technical and Economic Committee of the European Commission (STECF-EC), as well as fleet data retrieved from the European vessel register (http://ec.europa.eu/fisheries/fleet/index.cfm) and scientific studies.

Landing data by main group of species (i.e., demersal fish, small-pelagics, elasmobranchs, crustaceans, cephalopods) and area were obtained from the GFCM marine capture production database 1970-2014 (http://www.fao.org/gfcm/data/ capture-production-statistics/en/). This was complemented for EU GSAs with data from the JRC database on Mediterranean and Black Sea fisheries (https://stecf.jrc.ec.europa.eu/dd/medbs) as well as Italian data included in Mannini and Sabatella (2015).

Fishing mortality and $\mathrm{F}_{\mathrm{MSY}}$ values were compiled from stock assessment forms produced by both the GFCM and STECF working groups in stock assessment from 2002 to 2014 and summarized by Cardinale and Scarcella (2017).

Reported landing data in each GSA were contrasted with fleet capacity, calculated as total number of trawl vessels, and dimension of the continental shelf (depth range: 0-200 m). This latter was derived from a depth layer downloaded from Marspec database (http://www.marspec.org/). 


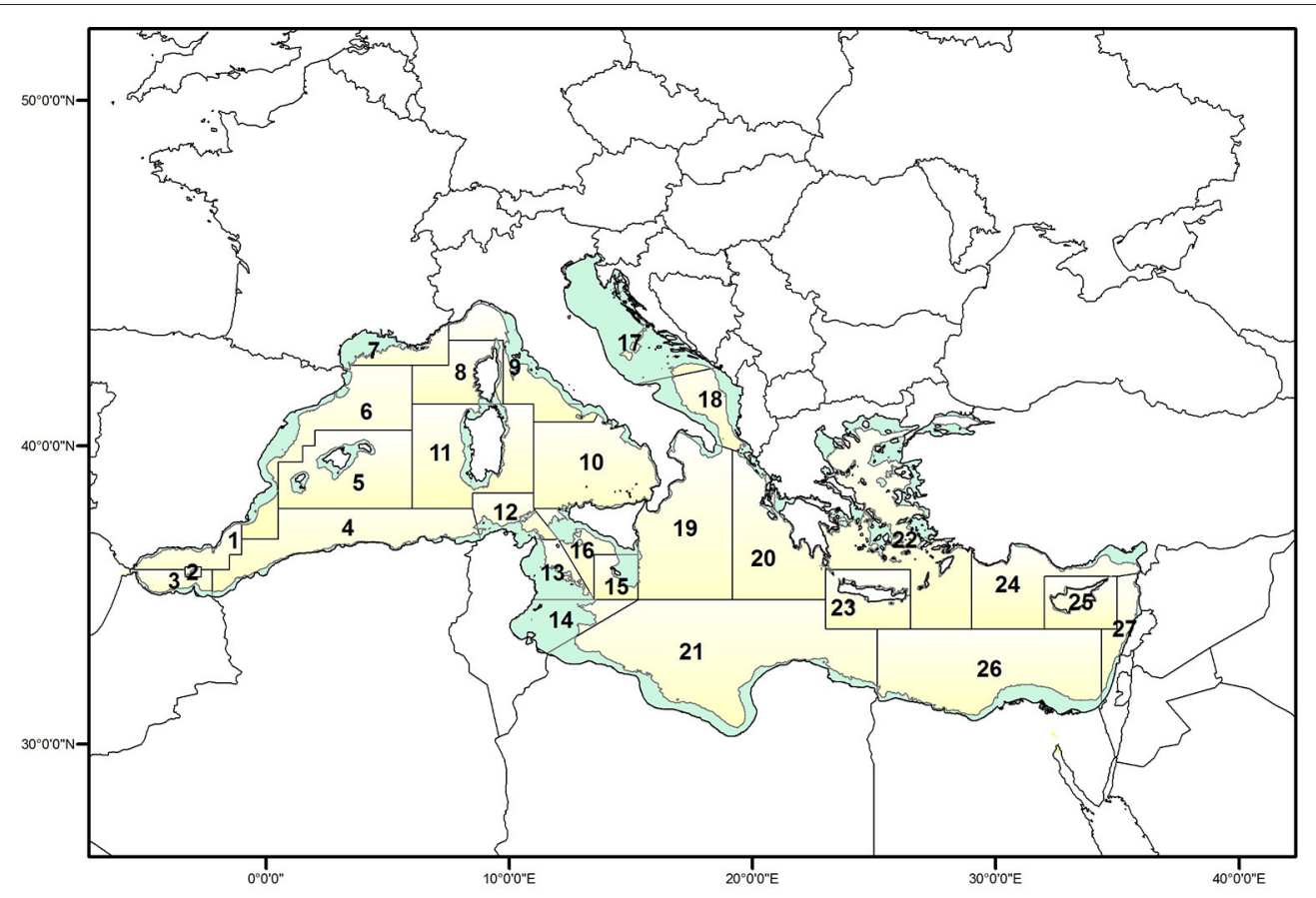

FIGURE 1 | Mediterranean FAO-GFCM Geographical Sub-Areas (GSAs). The continental shelf (0-200 m) is also shown. 1, Northern Alboran Sea; 2, Alboran Island; 3, Southern Alboran Sea; 4, Algeria; 5, Balearic Islands; 6, Northern Spain; 7, Gulf of Lions; 8, Corsica Island; 9, Ligurian and North Tyrrhenian Sea; 10, South Tyrrhenian Sea; 11.1, Sardinia (west); 11.2, Sardinia (east); 12, Northern Tunisia; 13, Gulf of Hammamet; 14, Gulf of Gabes; 15, Malta Island; 16, South of Sicily; 17, Northern Adriatic; 18, Southern Adriatic Sea; 19, Western Ionian Sea; 20, Eastern Ionian Sea; 21, Southern Ionian Sea; 22, Aegean Sea; 23, Crete Island; 24, North Levant; 25, Cyprus Island; 26, South Levant; 27, Eastern Levant Sea.

\section{Ecosystem Indicators}

Indicators were obtained from ecosystem models, which are standardized quantitative representations of main biological structure of the ecosystem, from primary producers to top predators. A set of available ecosystem models were selected to fulfill the following aspects: (i) represent substantial parts of each Mediterranean GSA (i.e., the model domain was large enough); (ii) have been well-documented in scientific literature; (iii) were developed for addressing fishing issues, thus they embed detailed description of fisheries landing and discards. The selected ecosystem models, although not available for all GSAs, permit to derive a set of indicators summarizing ecosystem effects of fishing to highlight impact of fishing on ecosystem structure and functioning. In particular we reported total ecosystem biomass (TB), total catches (TC), and the ratio between total catches and primary production (gross efficiency, GE). Moreover, from models were obtained footprint-like measure of fishing pressure, i.e., the primary production required to sustain catches (PPR; Pauly and Christensen, 1995), which together with information on primary production and the mean trophic level of the catches (mTLc; Pauly et al., 1998) provide a framework for assessing status of fisheries (Tudela, 2000; Tudela et al., 2005). These indicators are combined in the Loss in secondary production (L index), an index that allows assessing the ecosystem overfishing level since reference levels in terms of probability of the ecosystem to be sustainably fished ( $\mathrm{p}_{\text {sust }}$ ) were empirically defined (Libralato et al., 2008). Such indices collected for the set of available models provide an evaluation of ecosystem status by GSA.

As measures of the possible exposure to the indirect effects of climate change we derived the number of non-indigenous fish species recorded in each GSA. This was summarized from the CIESM Atlas of exotic species in Mediterranean (http://www.ciesm.org/online/atlas/) and complemented with supplementary bibliographic information from specific areas (Katsanevakis et al., 2009; Evans et al., 2015).

\section{RESULTS}

\section{Effort and Landings Data by GSA}

The Mediterranean fishing fleet is made up by about 72,600 vessels of which $85.5 \%$ are artisanal vessels using a variety of gears (e.g., trammel nets, gillnets, longlines, traps, etc.), about $9 \%$ are trawlers and $5 \%$ purse seiners and pelagic trawlers (Table 1, dredges were excluded). Fleet data show major differences across the Mediterranean GSAs. The largest artisanal fleets occur in Tunisia (GSAs 12-14), Aegean Sea (GSAs 22-23), and Northern Adriatic (GSA 17), whilst trawlers are mainly concentrated in Egypt (GSA 26), Adriatic (GSAs 17-18), and Algeria (GSA 4, Table 1). In terms of fishing pressure on the shelf, the area with the highest number of artisanal vessels per $\mathrm{km}^{2}$ are the Levantine Sea (GSA 27), Cyprus (GSA 25), Morocco (GSA 3), Algeria (GSA 4), Eastern Ionian Sea (GSAs 20, Figure 2A). A different pattern occurs for trawlers where the 


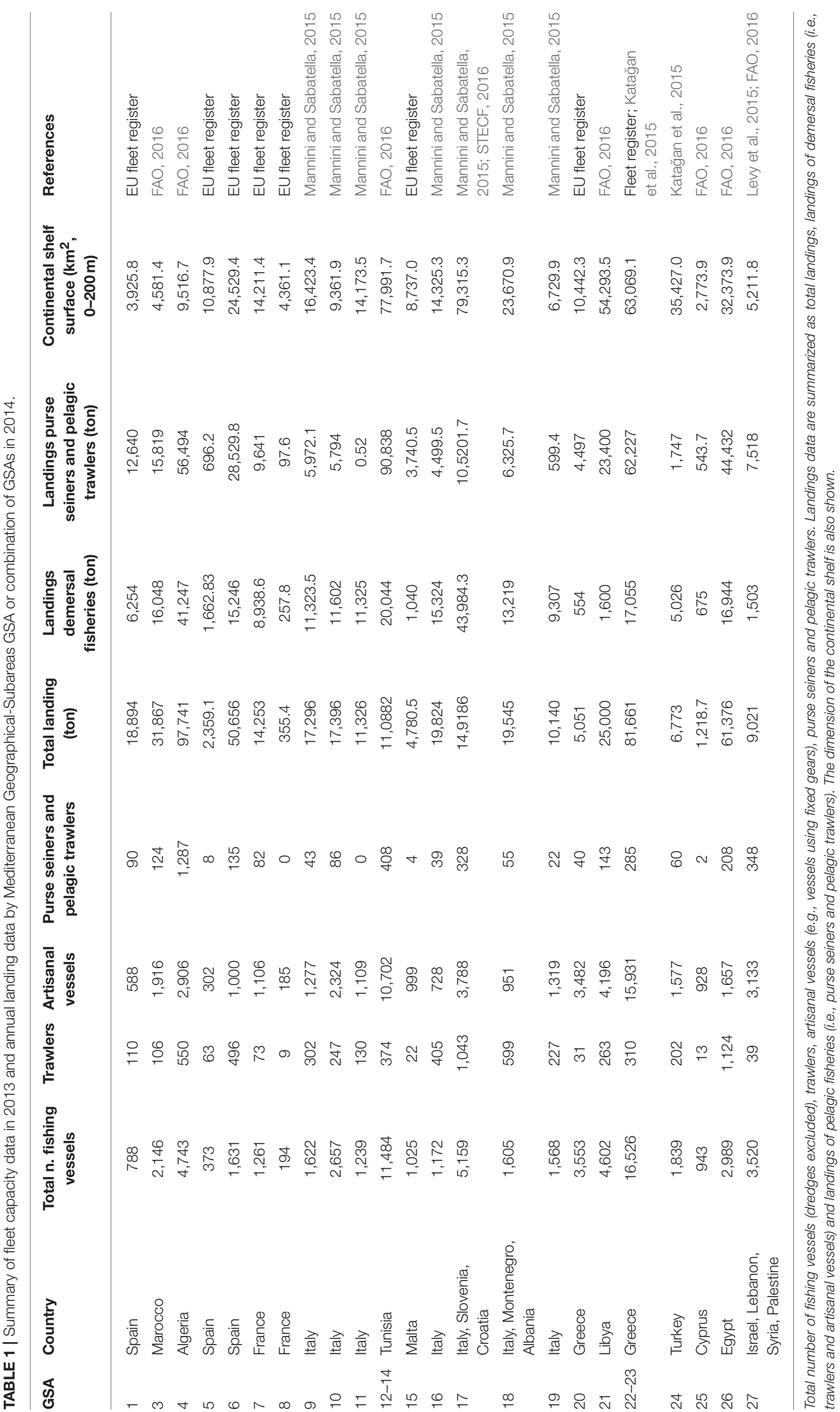



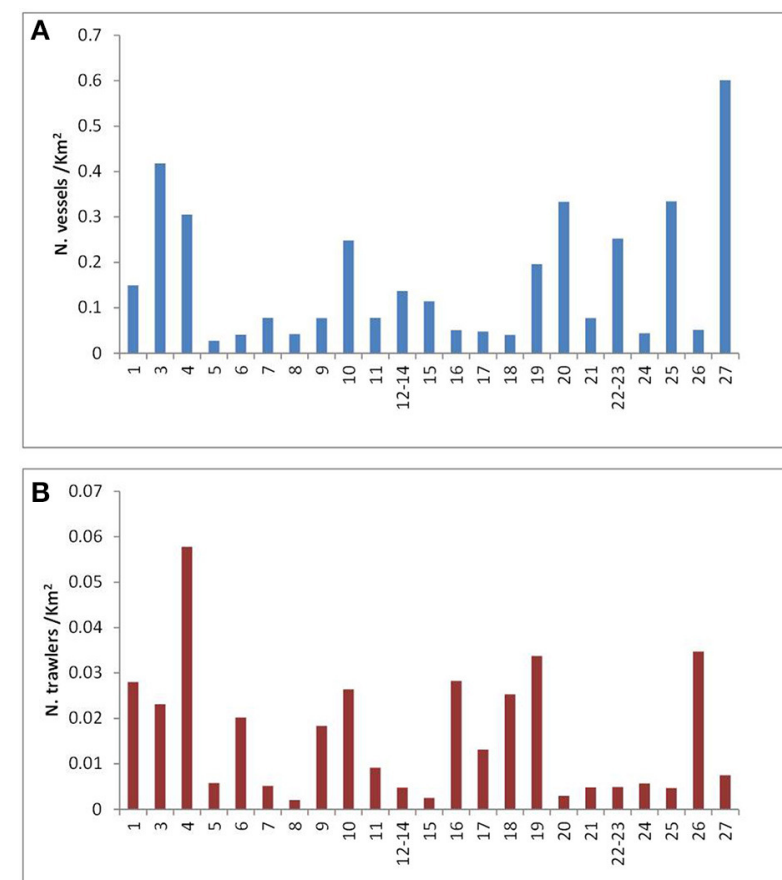

FIGURE 2 | Fishing pressure on the Mediterranean continental shelf, as n. vessel $\mathrm{km}^{-2}$, by GSA and fleet: (A) artisanal vessels; (B) trawlers (data derived from Table 1).

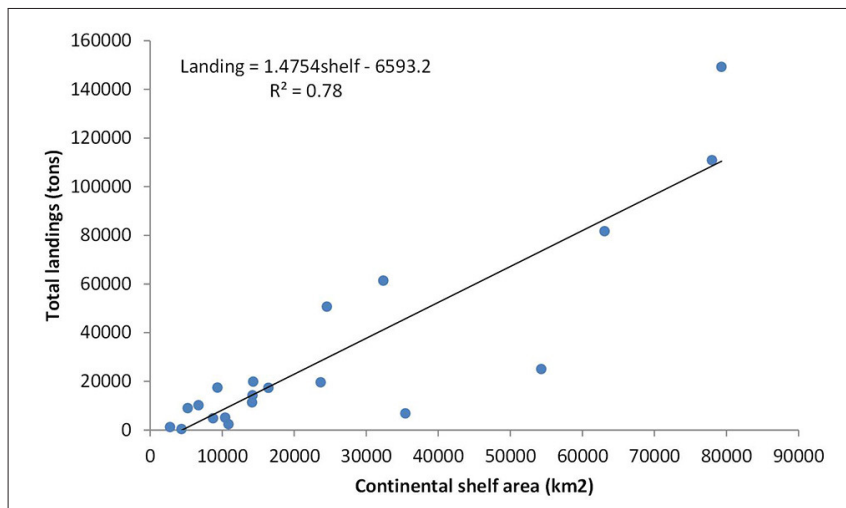

FIGURE 3 | Relationships between the dimension of the continental shelf area of GSAs and the reported total annual landings (GSAs 1-3 are excluded, data shown in Table 1).

highest concentration is found in Algeria (GSA 4), Egypt (GSA 26), Western Ionian Sea (GSA 19), Southern Sicily (GSA 16), Southern Adriatic Sea (GSA 18), Northern Alboran Sea (GSA 1) (Figure 2B).

The annual landings observed in the different GSAs resulted linearly correlated $\left(r^{2}=0.78, p<0.01\right)$ with the dimension of the continental shelf (0-200 $\mathrm{m}$ depth, Figure 3$)$. This appears therefore a key factor in constraining the productivity potential of Mediterranean fisheries.

\section{Temporal Trend in Landings}

The estimated total production of demersal and small pelagics species derived from different statitical sources was about 766,600 ton in 2014 similar to the figure that can be obtained from the GFCM capture data (727,000 tons). The landings of demersal species showed large differences among GSAs (Table 1): the area with the highest annual production was the Central-North Adriatic (GSA 17) with about 44,000 t, followed by the Algeria's GSA 4 (41,000 t), Tunisian GSAs (20,000 t), Agean Sea and Egypt (about 17,000 t each), Morocco $(16,000 \mathrm{t}$ ) and finally South of Sicily $(14,000 \mathrm{t})$.

According to the GFCM data, small pelagics (anchovy, sardine and other clupeids) accounted for 333,174 tons while demersal species achieved 394,327 tons. The temporal trend in annual production of demersal fish, crustaceans, cephalopods and small pelagics showed a rapid increase from 70s to the beginning of 90s followed by a declining trend since then. A different picture comes out disaggregating capture data by European (i.e., Spain, France, Italy, Slovenia, Croatia, Montenegro, Albania, Greece, Malta, Cyprus) and non-European countries (i.e., Turkey, Syria, Lebanon, Egypt, Libya, Tunisia, Algeria, Morocco). The reduction trend is determined only by a decreases in the landings of European countries for all the groups but the crustaceans. The landings of non-European countries was featured by a different pattern where a reduction in small pelagics, demersal fish and elasmobranchs occurred only in the last 5-10 years and partially compensated by a continuous increasing in cephalopods and crustaceans landings (Figure 4).

\section{Exploitation Status of Commercial Stocks}

Data for more than 80 stocks of fish and crustaceans assessed in the period 2002-2014 (Table 2) showed that for $90 \%$ of them the current fishing mortality (F) is higher than the fishing

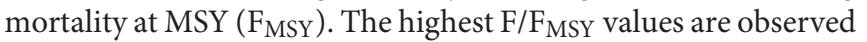
for demersal fish, particularly hake (Merluccius merluccius), black bellied anglerfish (Lophius boudegassa), and red mullet (Mullus barbatus). Most of the assessed stocks of crustaceans and small-pelagics are featured by $F / F_{M S Y}$ values between 1 and 2. In general, there are large differences between GSAs in the overexploitation status of species. For example red mulled (M. barbatus) appears sustainable exploited in GSAs 10 (South Tyrrhenian) and 18 (South Adriatic) and highly overexploited in GSAs 5 (Balearic) and 11 (Sardinia).

\section{Ecosystem Indicators}

Indicators derived from models (Table 3) showed large variability in total ecosystem biomass, ranging from 21.31 ton $/ \mathrm{km}^{2}$ in Ionian Sea model to $130 \mathrm{ton} / \mathrm{km}^{2}$ in Northern Adriatic Sea. There seems to be very poor relationship between total biomass and total catches $\left(R^{2}=0.0394\right)$. Generally, higher biomasses in the system resulted in lower mTLc. Therefore, PPR\% of the catches resulted positively related to total ecosystem biomass $\left(R^{2}=0.26\right)$. GE was very low for Tyrrhenian and Gulf of Gabes (GE < 0.001) and high for Catalan in the 2000s and Greek Ionian Sea (0.0034 and 0.0040 respectively). Placing PPR\% and mTLc in a combined context resulted in systems very likely sustainably fished (Aegean Sea and Gulf of Gabes) in 


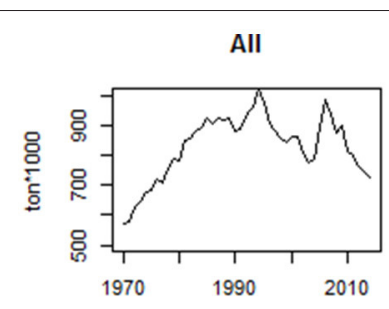

Crustaceans

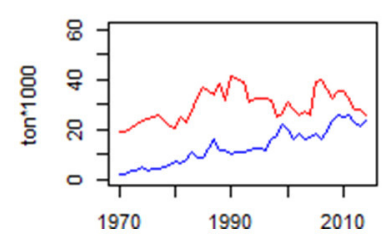

Small pelagics

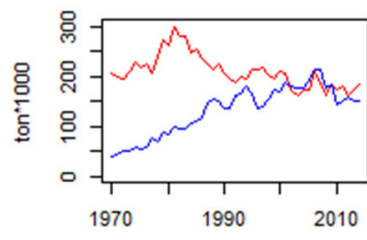

Cephalopods

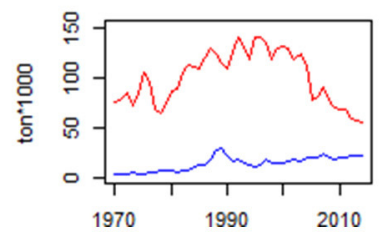

Demersal fish

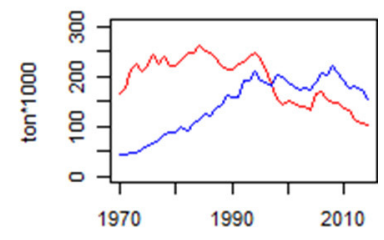

Elasmobranchs

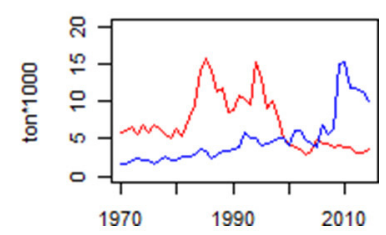

FIGURE 4 | Trend in annual landings of small pelagics, demersal fish, crustaceans, cephalopods, and elasmobranchs in EU (red line) and non-EU (blue line) Mediterranean GSAs. Data were retrieved from the GFCM capture fisheries database (http://www.fao.org/gfcm/data/capture-production-statistics/en/ ?platform=hootsuite).

contrast to other heavily exploited (Catalan Sea and Adriatic Sea, Figure 5A). The quantitative framework provided by Loss in secondary production index and $\mathrm{p}_{\text {sust }}$ (Libralato et al., 2008) resulted in a very critical situation for most of the exploited areas represented by the ecosystem models (Figure 5B). Only Gulf of Gabes, Eastern Ionian, and Aegean Sea were identified as models with sustainable fisheries. Conversely the Adriatic Sea appeared the most critical situation with a probability to be sustainable fished around 20\% (Figure 5B).

We used the total number of non-indigenous fish species by GSA as an index to exposure to environmental change. The map in Figure 6 shows main spatial difference among GSAs, with the Eastern basin featured by a high number of new species (94 in Levantine Sea-GSA 27). In contrast, the number of non-indigenous species is low in Central Mediterranean (e.g., Tyrrhenian Sea, Sardinia, Balearic Islands). An intermediate level of non-indigenous species can be found along the African coasts, where new species from the Red Sea and South Atlantic can overlap.

\section{DISCUSSION}

There is an increased concern about the status of Mediterranean ecosystem in relation to the sustainability of the current level of fisheries exploitation. Several studies have discussed how the unbalanced fishing in several areas of the Mediterranean is undermining the productivity of both commercial stocks and fisheries activities highlighting the need for a new management strategy aimed at rebuilding overexploited stocks (Colloca et al., 2013; Vasilakopoulos et al., 2014).

However, rarely the impact of fishing has been analyzed at the basin scale and accounting for both the status of the single stocks and the ecosystem. Most of the studies carried out in the last 10 years have focused on EU Mediterranean countries where data of transversal (i.e., catch and effort), biological (i.e., size/age composition of the commercial stocks, biological parameters) and socio-economic indicators are routinely collected on a year basis within the EU-Data Collection Framework (DCF). Since 2008, these data, used to provide advice on the status of the stocks in EU waters within the STECF working groups, have depicted an overall status of overfishing with few exceptions (STECF, 2014, 2016). Although a similar activity has been also developed by the GFCM for stocks in non-EU GSAs, the status of fisheries and stocks in these non-EU areas is less clear due to more scattered data and less commitment in performing standard data collection and stock assessments.

In this study, we revised multiple sources of data on fisheries and stocks from both EU and non-EU GSAs to provide an overall picture of fisheries trends in Mediterranean Sea accounting also for the most relevant effects on the ecosystem.

\section{Spatio-Temporal Trend in Fishing Effort and Landings}

Currently, the Mediterranean ecosystem is exploited by about 72,600 vessels most of which (85\%) are artisanal boats using many different fishing gears. The artisanal fishing component of the fleet is still extremely important for the socio-economy of many coastal communities other than a source of food, also for representing an important cultural heritage with relevant implication for activities related to the tourism. The main artisanal fleets are concentrated in Aegean Sea (GSAs 22-23); Tunisia (GSAs 12-14), Northern Adriatic (GSA 17), Libya (GSA 21), East Ionian Sea (GSA 20), Algeria (GSA 4), Morocco (GSA 3). The distribution of trawlers indicate that they concentrate mostly in Adriatic GSAs (GSAs 17 and 18), Egypt (GSA 27), Algeria (GSA 4), and North West Spain (GSA 6). Another large component of trawler fleet is located in the Strait of Sicily (GSAs 12-16), where 785 trawlers from Italy, Malta, and Tunisia exploit shared resources also in international waters.

Mediterranean GSAs are however featured by large differences in the dimension of the continental shelf which in turn determine 


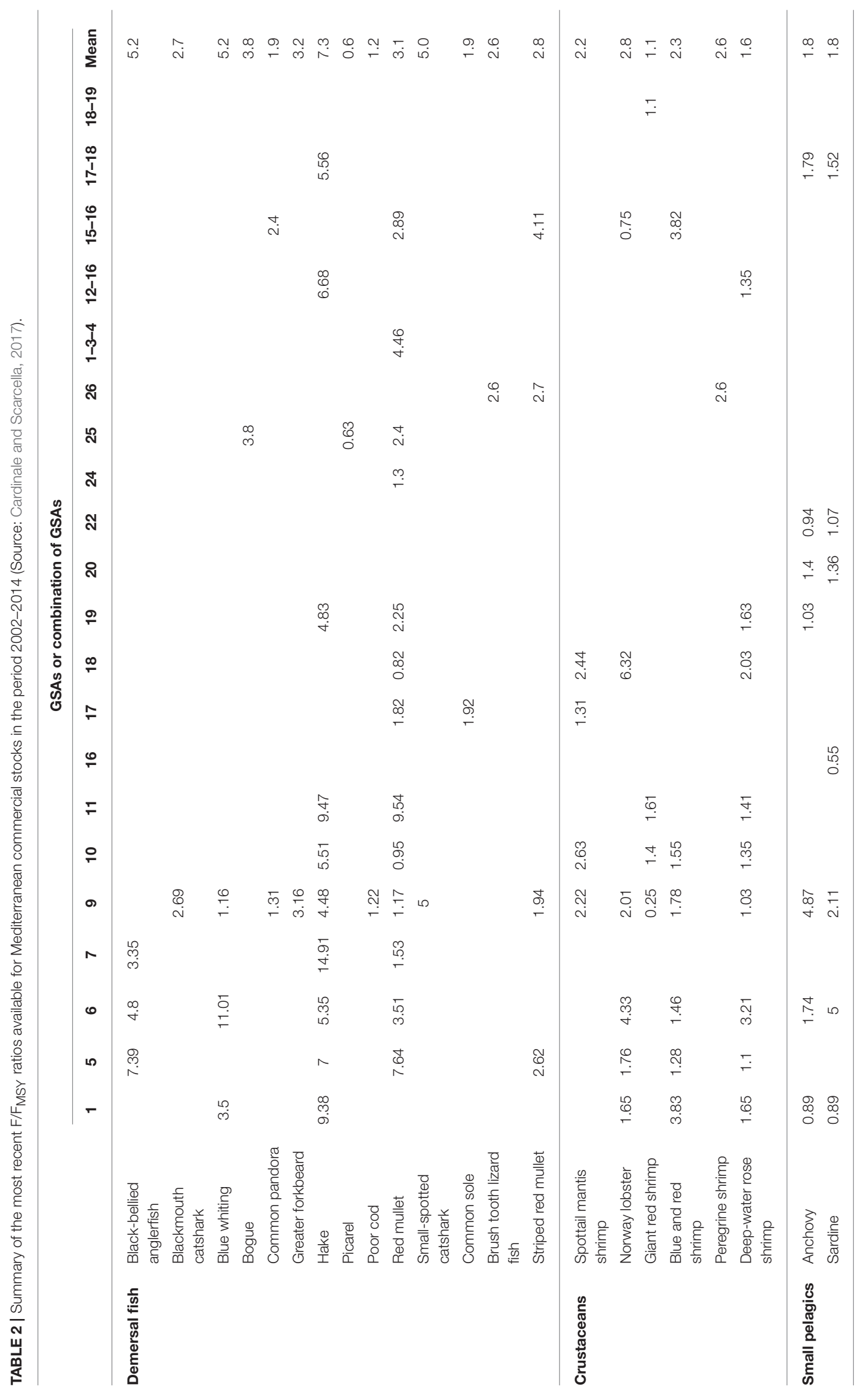




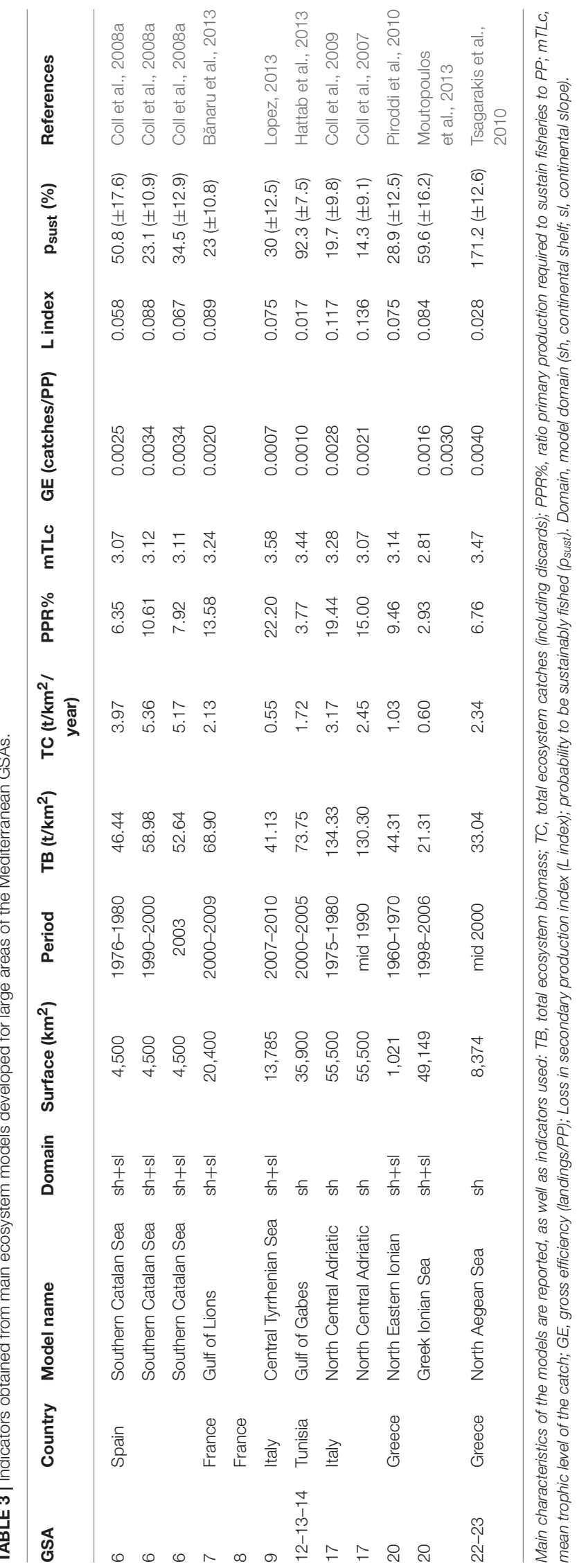

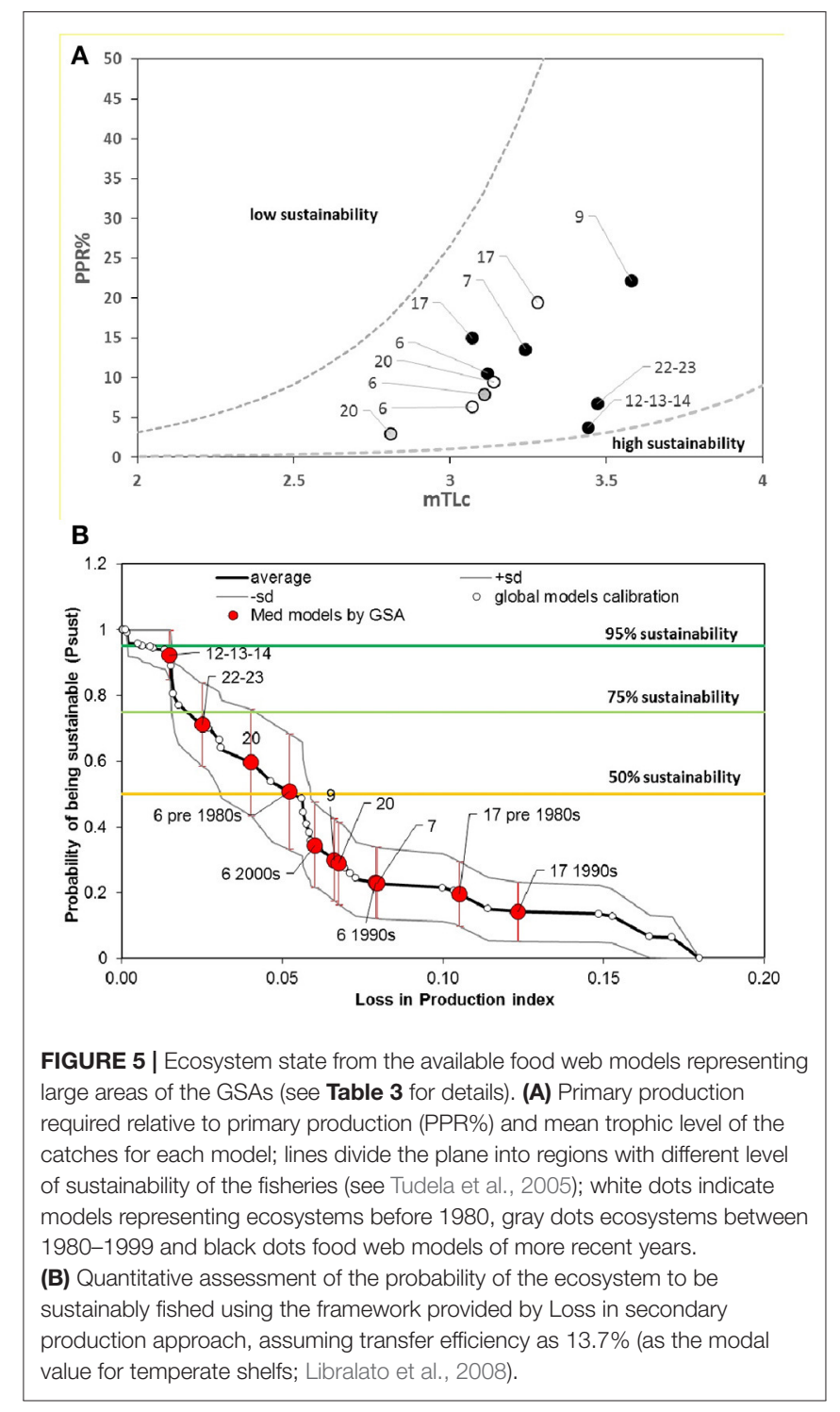

also large dissimilarities in fishing pressure (i.e., vessel $\mathrm{km}^{-2}$ ). Our analysis show that differences in fisheries productivity between different areas can be largely explained by differences in the dimension of the continental shelf, which is thus resulting as one of the most relevant factor constraining fisheries productivity.

Landings data from GFCM capture statistics indicated that the fishing landings of the EU countries declined since mid '90s for the main taxa with the exception of crustaceans, whose landings was substantially stable in the last 30 years. It is worth noting, however, that the catch trend appears completely different in non-EU countries. Here the annual landings of small pelagic and demersal fish species is increasing since 70 s and only in the last 5-10 years a decreasing trend is noticeable. Moreover, crustaceans, elasmobranchs, and cephalopods landings are still increasing. The stable or increasing pattern of crustaceans also in EU waters can be the results of a combination of effects, where the ecosystem 


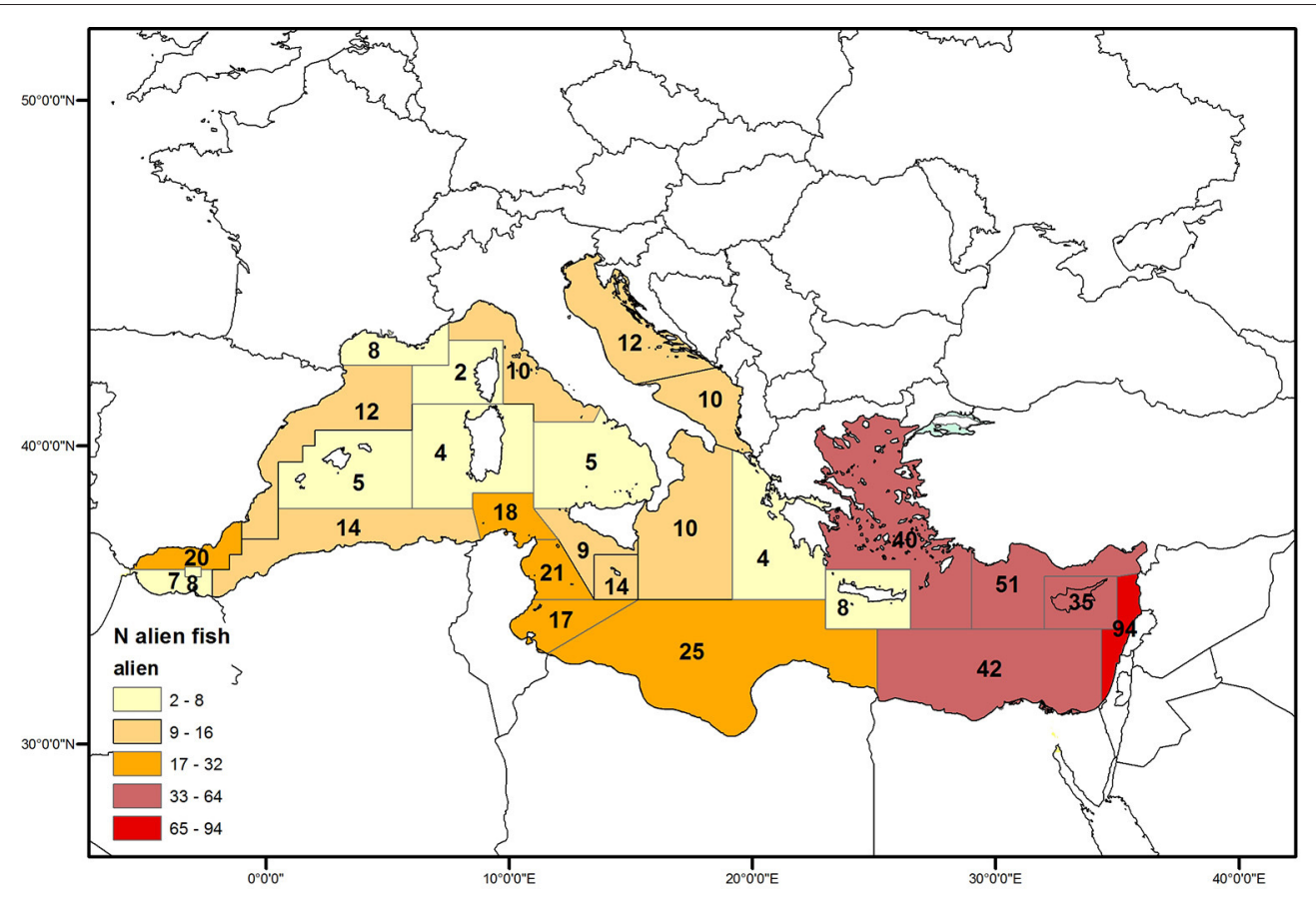

FIGURE 6 | Number of non-indigenous species by GSA. Data from the CIESM Atlas of Exotic Species in the Mediterranean (http://www.ciesm.org/online/atlas/).

change can be one of the most important. Temporal trend of increasing abundance of decapod crustaceans simultaneous with a decreasing of fish has been documented for the bathyal assemblages of the Western Mediterranean (Cartes et al., 2009). In this area, the landings of blue and red shrimp (Aristeus antennatus), the main target species of deep trawling, depends also by the climatic condition over the Western Mediterranean (Maynou, 2008). Similarly, the abundance of the deep-water rose shrimp (Parapenaeus longirostris), one of the most important commercial shrimp in Mediterranean, is increasing in the Tyrrhenian and Ligurian Seas, with an important effect due to the increasing in water temperature (Ligas et al., 2011; Colloca et al., 2014).

Current increasing landings of crustacean can also result from a sequential overexploitation with trawlers progressively moving from one resource to another in relation to their abundance, profitability and market conditions. Furthermore, a possible role might also by played by a combined effect of predation release, i.e., by the major removal by fisheries of their fish predators (e.g., as detected in N Atlantic; Worm and Myers, 2003), and of scavenging behavior, i.e., their potential advantage on feeding on large amounts of discards produced by Mediterranean fisheries (Tsagarakis et al., 2014). While these aspects need to be furtherly explored, the different temporal catch trends between EU and non-EU GSAs suggest that fishing effort in the two areas has been following an opposite development. Whilst the fishing capacity of European Mediterranean countries decreased in the last 20 years as effects of the decommissioning schemes of the EU with a subsequent reduction in landings, an increasing in fishing capacity cannot be excluded in other Mediterranean areas (SamyKamal, 2015).

\section{Impact of Fishing on Commercial Stocks and By-Catch Species}

Results of the stock assessments carried out in the last 10 years clearly show that the ongoing fishing pressure is determining a generalized overfishing status of commercial stocks, which appears more relevant for demersal fish. Overfishing is undermining the economic performance of EU Mediterranean fleets, as summarized by the negative trend in economic indicators (e.g., Italian fleets, STECF, 2015), thus making the sector more exposed to the negative effect of the general economic crisis. A negative picture on the effect of poorly regulated fishing activities on Mediterranean fish communities came out also by the assessment done by the International Union for Conservation of Nature (IUCN; Abdul Malak et al., 2011; Nieto et al., 2015) where among the 519 native marine fish species and subspecies assessed in term of conservation status in Mediterranan Sea, 43 species (7.5\%) were classified in threatened categories (critically endangered, endangered, or vulnerable). Of this group, 31 species are elasmobranchs making the Mediterranean the region in the world with the higher proportion of threatened species of sharks and rays (Dulvy et al., 2014).

The critical status of elasmobranchs was highlighted by several studies showing a worrisome long term decline (Fortibuoni et al., 2010) accelerated in last decades. For example, pelagic sharks declined by more than 95\% during the last century (Ferretti et al., 2008), whilst demersal sharks, such as smooth-hounds (Mustelus 
spp.), disappeared from most of the West Mediterranean in '70s and '80s (Massutí, 1971; Aldebert, 1997; Maynou et al., 2011; Ligas et al., 2013; Fortibuoni et al., 2016; Colloca et al., 2017).

The few geographic sectors where elasmobranchs still show viable populations for local fisheries are those featured by extended continental shelves (e.g., North Adriatic, South Tunisia and Libyan coasts, South of Sicily, and Malta). In these areas the elasmobranchs populations are likely maintained thanks to the occurrence of untrawable areas providing refuge opportunities, a moderate level of fishing intensity (e.g., Turkish coasts, Lybian waters) or a combination of these factors (see Bradai et al., 2012). However, the rapid increasing catches of elasmobranchs in non-EU waters in the last 20 years, shown by the GFCM data (Figure 4), can be a worrisome indication of an increased depletion risk for these "residuals" populations.

\section{Impact of Fishing on the Ecosystem}

In this study, we made an attempt to summarize the impact of fishing on the ecosystem of different GSAs to understand how much the negative signals derived from single-species models can be also detected at the multispecies level. Although the domain of the ecosystem models never encompassed the whole GSA, the models represented exploited key areas large enough to be considered indicative of the status of the GSA ecosystem, although within GSA there might be areas with contrasting local situations. Synthetic indicators directly derived from models such as total biomass, total catches and mTLc (mean trophic level of the catches) for each ecosystem highlight the difficulties in grasping the ecosystem effects of fishing without considering the productivity and the energetics behind each caught species. For instance the general pattern of higher catches and lower mTLc for ecosystems with higher total biomass (Table 3) is related to patterns in the primary productivity across GSAs. This highlight the difficulties for these indicators to detect impacts of fishing, because larger productivity supports ecosystem with heavier exploitation and the lowering of mTLc is simply the result of nonproportional effects of productivity across trophic level. That is why GE, which was suggested as an index of fishing pressure (Christensen et al., 2008), might be misleading in indicating ecosystem overfishing.

Primary production required to sustain catches, instead, accounts for the energy needed to produce caught biomasses at different TL and when scaled to actual PP for obtaining PPR\% results in an indicator useful for comparing fishing pressure across ecosystems with very different productivity as the different Mediterranean GSAs. Contrasting PPR\% with mTLc using a consolidated framework (Tudela, 2000; Libralato et al., 2005, 2008; Tudela et al., 2005; Coll et al., 2008b), moreover, allows to highlight ecosystem sustainability of fisheries. Areas that resulted exploited sustainably are Gulf of Gabes, as well as Eastern Ionian and Aegean Sea with probability to be sustainably fished ( $\left.\mathrm{p}_{\text {sust }}\right)$ of $92.3 \%( \pm 7.5), 59.6 \%( \pm 16.2 \%)$, and $71.2 \%( \pm 12.6 \%)$, respectively. The high sustainability of fisheries in these areas is coherent with fishing pressure characterized by low number of vessels per unit of shelf area for Tunisia and for the large prevalence of artisanal/small scale fisheries in GSA 20 and
22. Conversely GSA 6, 9, and 17 showed very low ecosystem sustainability of the fisheries, with the Northen Central Adriatic Sea (GSA 17) the lowest $14.3 \%( \pm 9.1)$. These figures are coherent with the high fishing pressure on these systems (number of trawlers per unit surface of shelf). Ecosystems in GSA 6, 9, and 17 appear thus overexploited with considerable losses in secondary productions and represent areas where exploitation is ecologically inefficient and also characterized by economically low efficient fisheries.

Unfortunately not all GSAs have exemplificative ecosystem model to analyse, and clearly the ones available suffer for representing different periods in the last decades, might embeds different biological resolution and processes, and might have different degree of accuracy according to data availability. Nevertheless, the picture is coherent with fishing capacity, effort and catches for the overlapping GSAs. Results point to general good conditions for areas dominated historically by artisanal and small scale fisheries such as the Greek Ionian Sea, GSA 20, (Moutopoulos et al., 2013) or where fisheries is developed but still working within profitable conditions such as the Tunisian GSAs (Hattab et al., 2013). Areas such as the western GSA17, with long history of fisheries exploitation (Fortibuoni et al., 2010), with very impacting gears active (such as the rapido trawling; Pranovi et al., 2000), with several ecosystem impacts documented (e.g., Giani et al., 2012) and with several stocks assessed as overfished (Table 2), resulted to be in a condition that can be summarized as a low profitable bio-economic equilibrium.

\section{CONCLUSIONS}

It is straightforward that the current level of fishing pressure in the Mediterranean basin, exerted by a large variety of fishing vessels and fishing gears, has impaired the productivity of commercial stocks, increased the extinction risks for sensible species, such as elasmobranchs, and contributed to disrupt the productivity and functions of the ecosystem.

We showed that single species and ecosystem models return a coherent pattern where ecosystem overfishing is combined with a high proportion of commercial stocks out of safe biological limits. This is in turn the result of a prolonged high fishing pressure where the effect of diffuse artisanal fleets is exacerbated by high pressure from vessels using towed gears (e.g., bottom and pelagic trawlers, beam trawlers). The fishing effort has increased in an uncontrolled way for decades in many Mediterranean areas (Garcia, 2011), and although measures to freeze the effort and reduce the capacity of the fleet are ongoing in EU Mediterranean countries also thanks to EU regulations, there are not yet clear signs of an inversion of the trend. As a matter of fact, Cardinale and Scarcella (2017), clearly shown that one of the major reasons for the alarming situation of Mediterranean Sea stocks can be found in the ineffectiveness of the putative effort reductions to control fishing mortalities, the continuous non-adherence to the scientific advice, and the existence of ineffective national management plans as a primary management measure.

It is widely recognized that managing multi-species, multi-fleets fisheries is a complex task where the achievement 
of single species targets (i.e., MSY) for a multiple stocks can be challenging due to species interactions (e.g., prey-predator relationships, competition, etc.) but also due to indirect interactions of mixed fisheries (Walters et al., 2005; Mackinson et al., 2009), especially in a fast changing ecosystem such as the Mediterranean. The rapid warming, combined with the expansion of non-indigenous species is definitely changing the suitability of the habitats for traditional commercial species with effects on their resilience to fishing (Libralato et al., 2015). The recent collapse of small pelagic fishery in the Gulf of Lions is a clear example where poor fish growth, size and body condition and ultimately biomass seem to be due to bottom-up control characterized by changes in food availability and increasing potential trophic competition (Brosset et al., 2016). Exaggerated fishing pressure represents a threat for populations making them more fragile and less resilient to other pressures and changes, and ultimately increasing the risk of collapse for the fisheries themselves.

In this context, the development of a more effective management regime for Mediterranen fisheries is extremely urgent to prevent that unregulated fishing and climate forcing might disrupt the secondary productivity of the ecosystem with major impacts on the goods and services provided.

The poor management is likely the result of the intrinsic complexity of managing human activities in the Mediterranean basin, where nations with major differences in the governance systems, socio-economic priorities and development objectives, share common natural resources (Micheli et al., 2013). However, a different result in terms of governance and sustainability was expected for fisheries in EU Mediterranean countries considering the policy objectives identified by regulations such as the Common Fisheries Policy (CFP), and the EU reg. 1967 since 2006.

Only recently were set the first attempts to develop management strategies at the international scale by GFCM with the support of the EU, as for example for deep water rose shrimp and hake fisheries in the Strait of Sicily. The ongoing process in Mediterranean European waters appears however too slow to achieve the MSY for the main commercial stocks by 2020 .

The Mediterranean EU regulation 1967/2006 and the CFP have mostly failed in their mandate to achieve sustainability for fisheries in EU Mediterranean waters, thus not providing

\section{REFERENCES}

Abdul Malak, D., Livingstone, S. R., Pollard, D., Polidoro, B. A., Cuttelod, A., Bariche, M., et al. (2011). Overview of the Conservation Status of the Marine Fishes of the Mediterranean Sea. Gland; Malaga: IUCN.

Abelló, P., Abella, Á., Adamidou, A., Jukic-Peladic, S., Maiorano, P., and Spedicato, M. T. (2002). Geographical patterns in abundance and population structure of Nephrops norvegicus and Parapenaeus longirostris (Crustacea: Decapoda) along the European Mediterranean coasts. Sci. Mar. 66(Suppl. 2), 125-141. doi: $10.3989 /$ scimar.2002.66s 2125

Aldebert, Y. (1997). Demersal resources of the Gulf of Lions (NW Mediterranean). Impact of exploitation on fish diversity. Vie Milieu 4, 275-284. long-term sustainability and profitability to the fishing enterprises (STECF, 2015). This is in contrast to what observed in recent years in NE Atlantic, where the actions already implemented under the CFP have led to an improvement in the status of many commercially important fish stocks toward levels that are capable of producing MSY (Cardinale et al., 2013). Although the high-level seminar on the state of stocks in the Mediterranean and on the CFP approach held in February 2016 (http://ec.europa.eu/fisheries/high-level-seminar-state-stocksmediterranean-and-cfp-approach_en) has stressed the need of urgent actions to inverse the ongoing negative trend, any major management action to quickly reverse the trend has been put in place so far.

Similar problems are being experienced throughout the world and for sure, several policy-oriented instruments have been enacted at the international level in recent years, which call upon relevant management bodies and Regional Fisheries Management Organizations (RFMOs) to be actively involved in the protection of marine biodiversity and sustainable use of fishery resources. In particular, the new CFP along with the most recently, UN SDG 14, FAO SO2, and the Aichi Targets all stress the importance of reducing overfishing and securing healthy ecosystems for the benefit of present and future generations.

\section{AUTHOR CONTRIBUTIONS}

FC: contribution to the design of the study, catch-effort review and analysis, and discussion of results; GS: contribution to the design of the study, stock assessments review, and discussion of results; SL: contribution to the design of the study, ecosystem models review and analysis, and discussion of results.

\section{ACKNOWLEDGMENTS}

This study was partially carried out within the EU project MareFrame: Co-creating Ecosystem-based Fisheries Management Solutions, Seventh Framework Programme (FP 7), grant agreement no. 613571. SL has been partially funded by the Flagship Project RITMARE-The Italian Research for the Sea-coordinated by the Italian National Research Council and funded by the Italian Ministry of Education, University and Research within the National Research Program 2011-2013. 
Caddy, J. F. (2000). Marine catchment basin effects versus impacts of fisheries on semi-enclosed seas. ICES J. Mar. Sci. 57, 628-640. doi: 10.1006/jmsc.2000.0739

Cardinale, M., and Scarcella, G. (2017). Mediterranean Sea: a failure of the European fisheries management system. Front. Mar. Sci. 4:72. doi: $10.3389 /$ fmars.2017.00072

Cardinale, M., Dörner, H., Abella, A., Andersen, J. L., Casey, J., Döring, R., et al. (2013). Rebuilding EU fish stocks and fisheries, a process under way? Mar. Policy 39, 43-52. doi: 10.1016/j.marpol.2012.10.002

Cartes, J. E., Maynou, F., Fanelli, E., Papiol, V., and Lloris, D. (2009). Long-term changes in the composition and diversity of deep-slope megabenthos and trophic webs off Catalonia (western Mediterranean): are trends related to climatic oscillations? Prog. Oceanogr. 82, 32-46. doi: 10.1016/j.pocean.2009.03.003

Christensen, V., Walters, C. J., Pauly, D., and Forrest, R. (2008). Ecopath with Ecosim Version 6: User Guide. Vancouver, BC: Fisheries Centre; University of British Columbia.

Coll, M., Palomera, I., Tudela, S., and Sardà, F. (2006). Trophic flows, ecosystem structure and fishing impacts in the South Catalan Sea, Northwestern Mediterranean. J. Mar. Syst. 59, 63-96. doi: 10.1016/j.jmarsys.2005.09.001

Coll, M., Palomera, I., Tudela, S., and Dowd, M. (2008a). Food-web dynamics in the South Catalan Sea ecosystem (NW Mediterranean) for 1978-2003. Ecol. Model. 217, 95-116. doi: 10.1016/j.ecolmodel.2008.06.013

Coll, M., Libralato, S., Tudela, S., Palomera, I., and Pranovi, F. (2008b). Ecosystem overfishing in the ocean. PLoS ONE 3:e3881. doi: 10.1371/journal.pone.0003881

Coll, M., Santojanni, A., Arneri, E., Palomera, I., and Tudela, S. (2007). An ecological model of the Northern and Central Adriatic Sea: analysis of ecosystem structure and fishing impacts. J. Mar. Syst. 67, 119-154. doi: 10.1016/j.jmarsys.2006.10.002

Coll, M., Santojanni, A., Palomera, I., and Arneri, E. (2009). Food-web dynamics in the North-Central Adriatic marine ecosystem (Mediterranean Sea) over the last three decades. Mar. Ecol. Prog. Ser. 381, 17-37. doi: 10.3354/meps07944

Coll, M., and Libralato, S. (2012). Contributions of food web modelling to the ecosystem approach to marine resource management in the Mediterranean Sea. Fish Fish. 13, 60-88. doi: 10.1111/j.1467-2979.2011.00420.x

Colloca, F., Cardinale, M., Maynou, F., Giannoulaki, M., Scarcella, G., Jenko, K., et al. (2013). Rebuilding Mediterranean fisheries: a new paradigm for ecological sustainability. Fish Fish. 14, 89-109. doi: 10.1111/j.1467-2979.2011.00453.x

Colloca, F., Enea, M., Ragonese, S., and Di Lorenzo, M. (2017). A century of fishery data documenting the collapse of smooth-hounds (Mustelus spp.) in the Mediterranean Sea. Aquatic. Conserv. Mar. Freshw. Ecosyst. doi: 10.1002/aqc. 2789. [Epub ahead of print].

Colloca, F., Mastrantonio, G., Jona Lasinio, G., Ligas, A., and Sartor, P. (2014). Parapenaeus longirostris (Lucas, 1846) an early warning indicator species of global warming in the central Mediterranean Sea. J. Mar. Sys. 138, 29-39. doi: 10.1016/j.jmarsys.2013.10.007

Cossarini, G., Lazzari, P., and Solidoro, C. (2015). Spatiotemporal variability of alkalinity in the Mediterranean Sea. Biogeosciences 12:1647. doi: 10.5194/bg-12-1647-2015

De Biasi, A. M., and Pacciardi, L. (2008). Macrobenthic communities in a fishery exclusion zone and in a trawled area of the middle Adriatic Sea (Italy). Cienc. Mar. 34, 433-444.

de Juan, S., Thrush, S. F., and Demestre, M. (2007). Functional changes as indicators of trawling disturbance on a benthic community located in a fishing ground (NW Mediterranean Sea). Mar. Ecol. Prog. Ser. 334, 117-129. doi: $10.3354 /$ meps334117

de Juan, S., and Lleonart, J. (2010). A conceptual framework for the protection of vulnerable habitats impacted by fishing activities in the Mediterranean high seas. Ocean Coast. Manag. 53, 717-723. doi: 10.1016/j.ocecoaman.2010.10.005

Dulvy, N. K., Fowler, S. L., Musick, J. A., Cavanagh, R. D., Kyne, P. M., Harrison, L. R., et al. (2014). Extinction risk and conservation of the world's sharks and rays. Elife 3:e00590. doi: 10.7554/eLife.00590

Evans, J., Barbara, J., and Schembri, P. J. (2015). Updated review of marine alien species and other 'newcomers' recorded from the Maltese Islands (Central Mediterranean). Mediterr. Mar. Sci. 16, 225-244. doi: 10.12681/mms.1064

FAO (2016). The State of Mediterranean and Black Sea Fisheries. General Fisheries Commission for the Mediterranean, Rome.
Ferretti, F., Myers, R. A., Serena, F., and Lotze, H. K. (2008). Loss of large predatory sharks from the Mediterranean Sea. Conserv. Biol. 22, 952-964. doi: 10.1111/j.1523-1739.2008.00938.x

Ferretti, F., Osio, G. C., Jenkins, C. J., Rosenberg, A. A., and Lotze, H. K. (2013). Long-term change in a meso-predator community in response to prolonged and heterogeneous human impact. Sci. Rep. 3:1057. doi: 10.1038/srep 01057

Fortibuoni, T., Borme, D., Franceschini, G., Giovanardi, O., and Raicevich, S. (2016). Common, rare or extirpated? Shifting baselines for common angelshark, Squatina squatina (Elasmobranchii: Squatinidae), in the Northern Adriatic Sea (Mediterranean Sea). Hydrobiologia 772, 247-259. doi: 10.1007/s10750-016-2671-4

Fortibuoni, T., Giovanardi, O., Pranovi, F., Raicevich, S., Solidoro, C., and Libralato, S. (2017). Analysis of long-term changes in a Mediterranean marine ecosystem based on fishery landings. Front. Mar. Sci. 4:33. doi: 10.3389/fmars.2017.00033

Fortibuoni, T., Libralato, S., Raicevich, S., Giovanardi, O., and Solidoro, C. (2010). Coding early naturalists' accounts into long-term fish community changes in the Adriatic Sea (1800-2000). PLoS ONE 5:e15502. doi: 10.1371/journal.pone.0015502

Galgani, F. (2015). Marine litter, future prospects for research. Front. Mar. Sci. 2:87. doi: 10.3389/fmars.2015.00087

Galil, B. S., Marchini, A., Occhipinti-Ambrogi, A., Minchin, D., Narščius, A., Ojaveer, H., et al. (2014). International arrivals: widespread bioinvasions in European Seas. Ethol. Ecol. Evol. 26, 152-171. doi: 10.1080/03949370.2014.897651

Garcia, S. M. (2011). Long-Term Trends in Small Pelagic and Bottom Fisheries in the Mediterranean: 1950-2008. Valbonne: Plan Bleu.

GFCM (2016a). Working Group on Stock Assessment of Demersal Species (WGSAD). Final report, GFCM and FAO headquarters, Rome, 74

GFCM (2016b). Working Group on Stock Assessment of Small Pelagics Species (WGSAD). Final report, GFCM and FAO headquarters, Rome, 66.

Giani, M., Djakovac, T., Degobbis, D., Cozzi, S., Solidoro, C., and Umani, S. F. (2012). Recent changes in the marine ecosystems of the northern Adriatic Sea. Estuar. Coast. Shelf Sci. 115, 1-13. doi: 10.1016/j.ecss.2012. 08.023

Hattab, T., Lasram, F. B. R., Albouy, C., Romdhane, M. S., Jarboui, O., Halouani, G., et al. (2013). An ecosystem model of an exploited southern Mediterranean shelf region (Gulf of Gabes, Tunisia) and a comparison with other Mediterranean ecosystem model properties. J. Mar. Syst. 128, 159-174. doi: 10.1016/j.jmarsys.2013.04.017

Katağan, T., Tokaç, A., Beşiktepe, Ş., Sea, A., Denizi, E., and Öztürk, B. (eds.). (2015). The Aegean Sea Marine Biodiversity, Fisheries, Conservation and Governance. Turkish Marine Research Foundation (TUDAV). Publication No: 41, Istanbul.

Katsanevakis, S., Tsiamis, K., Ioannou, G., Michailidis, N., and Zenetos, A. (2009). Inventory of alien marine species of Cyprus (2009). Mediterr. Mar. Sci. 10, 109-134. doi: $10.12681 / \mathrm{mms} .113$

Lazzari, P., Mattia, G., Solidoro, C., Salon, S., Crise, A., Zavatarelli, M., et al. (2014). The impacts of climate change and environmental management policies on the trophic regimes in the Mediterranean Sea: scenario analyses. J. Mar. Syst. 135, 137-149. doi: 10.1016/j.jmarsys.2013.06.005

Lazzari, P., Solidoro, C., Ibello, V., Salon, S., Teruzzi, A., Béranger, K., et al. (2012). Seasonal and inter-annual variability of plankton chlorophyll and primary production in the Mediterranean Sea: a modelling approach. Biogeosciences 9:217. doi: 10.5194/bg-9-217-2012

Lejeusne, C., Chevaldonné, P., Pergent-Martini, C., Boudouresque, C. F., and Perez, T. (2009). Climate change effects on a miniature ocean: the highly diverse, highly impacted Mediterranean Sea. Trends Ecol. Evol. 25, 250-260 doi: 10.1016/j.tree.2009.10.009

Levy, Y., Frid, O., Weinberger, A., Sade, R., Adam, Y., Kandanyan, U., et al. (2015). A small fishery with a high impact on sea turtle populations in the eastern Mediterranean. Zool. Middle East 61, 300-317. doi: 10.1080/09397140.2015.1101906

Libralato, S., Caccin, A., and Pranovi, F. (2015). Modeling species invasions using thermal and trophic niche dynamics under climate change. Front. Mar. Sci. 2:29. doi: 10.3389/fmars.2015.00029 
Libralato, S., Coll, M., Tudela, S., Palomera, I., and Pranovi, F. (2005). Quantifying Ecosystem Overfishing with a New Index of Fisheries' Impact on Marine Trophic Webs, Vol. 2024. Aberdeen: ICES CM 2005/M:23, 1-23.

Libralato, S., Coll, M., Tudela, S., Palomera, I., and Pranovi, F. (2008). Novel index for quantification of ecosystem effects of fishing as removal of secondary production. Mar. Ecol. Prog. Ser. 355, 107-129. doi: 10.3354/meps 07224

Ligas, A., Osio, G. C., Sartor, P., Sbrana, M., and De Ranieri, S. (2013). Long-term trajectory of some elasmobranch species off the Tuscany coasts (NW Mediterranean) from 50 years of catch data. Sci. Mar. 77, 119-127. doi: $10.3989 /$ scimar.03654.21C

Ligas, A., Sartor, P., and Colloca, F. (2011). Trends in population dynamics and fishery of Parapenaeus longirostris and Nephrops norvegicus in the Tyrrhenian Sea (NW Mediterranean): the relative importance of fishery and environmental variables. Mar. Ecol. 32, 25-35. doi: 10.1111/j.1439-0485.2011. 00440.x

Lleonart, J. (1993). Methods to analyse the dynamics of exploited marine populations: use and development of models. Sci. Mar. 57, 261-267.

Lopez, S. (2013). L'ecosistema del Mar Tirreno: Aspetti Strutturali, Funzionali, Effetti Della Pesca e Delle Interazioni Trofiche. Ph.D. thesis, Università degli Studi di Roma Sapienza.

Mackinson, S., Deas, B., Beveridge, D., and Casey, J. (2009). Mixed-fishery or ecosystem conundrum? Multispecies considerations inform thinking on longterm management of North Sea demersal stocks. Can. J. Fish. Aquat. Sci. 66, 1107-1129. doi: 10.1139/F09-057

Mannini, A., and Sabatella, R. F. (2015). Annuario sullo stato delle risorse e sulle strutture produttive dei mari italiani. Biol. Mar. Mediterr. 22(Suppl. 1), 358.

Massutí, M. (1971). El talud continental de las Islas Baleares. Su evolución bioceanótica. Evolución de los rendimientos e pesca. Prospecciones pesqueras y tecnología. Publicaciones Técnicas Dirección General Pesca Marítima 9, $13-112$.

Maynou, F., Sbrana, M., Sartor, P., Maravelias, C., Kavadas, S., Damalas, D., et al. (2011). Estimating trends of population decline in long-lived marine species in the Mediterranean Sea based on fishers' perceptions. PLoS ONE 6:e21818. doi: 10.1371/journal.pone.0021818

Maynou, F. (2008). Influence of the North Atlantic Oscillation on Mediterranean deep-sea shrimp landings. Clim. Res. 36, 253-257. doi: 10.3354/cr00746

Micheli, F., Halpern, B. S., Walbridge, S., Ciriaco, S., Ferretti, F., Fraschetti, S., et al. (2013). Cumulative human impacts on Mediterranean and Black Sea marine ecosystems: assessing current pressures and opportunities. PLoS ONE 8:e79889. doi: 10.1371/journal.pone.0079889

Moutopoulos, D. K., Libralato, S., Solidoro, C., and Stergiou, K. I. (2013). Toward an ecosystem approach to fisheries in the Mediterranean Sea: multi-gear/multispecies implications from an ecosystem model of the Greek Ionian Sea. J. Mar. Syst. 113, 13-28. doi: 10.1016/j.jmarsys.2012.12.002

Nieto, A., Ralph, G. M., Comeros-Raynal, M. T., Kemp, J., Criado, M. G., Allen, D. J., et al. (2015). European Red List of Marine Fishes. Publications Office of the European Union.

Parravicini, V., Azzurro, E., Kulbicki, M., and Belmaker, J. (2015). Niche shift can impair the ability to predict invasion risk in the marine realm: an illustration using the Mediterranean fish invaders. Ecol. Lett. 18, 246-253. doi: 10.1111/ele.12401

Pauly, D., and Christensen, V. (1995). Primary production required to sustain global fisheries. Nature 374, 255-257. doi: 10.1038/374255a0

Pauly, D., Christensen, V., Dalsgaard, J., Froese, R., and Torres, F. (1998). Fishing down marine food webs. Science 279, 860-863. doi: $10.1126 /$ science. 279.5352 .860
Piroddi, C., Bearzi, G., and Villy, C. (2010). Effects of local fisheries and ocean productivity on the northeastern Ionian Sea ecosystem. Ecol. Model. 221, 1526-1544. doi: 10.1016/j.ecolmodel.2010.03.002

Pranovi, F., Raicevich, S., Franceschini, G., Farrace, M. G., and Giovanardi, O. (2000). Rapido trawling in the northern Adriatic Sea: effects on benthic communities in an experimental area. ICES J. Mar. Sci. 57, 517-524. doi: 10.1006/jmsc.2000.0708

Samy-Kamal, M. (2015). Status of fisheries in Egypt: reflections on past trends and management challenges. Rev. Fish Biol. Fish. 25, 631-649. doi: 10.1007/s11160-015-9404-z

Smith, C. J., Papadopoulou, K. N., and Diliberto, S. (2000). Impact of otter trawling on an eastern Mediterranean commercial trawl fishing ground. ICES J. Mar. Sci. 57, 1340-1351. doi: 10.1006/jmsc.2000.0927

STECF (2014). Consolidated Advice on Fish Stocks of Interest to the European Union (STECF-14-24). Luxembourg: Publications Office of the European Union; EUR - Scientific and Technical Research Series.

STECF (2015). Annual Economic Report on the EU fishing fleet (STECF-15-07). Luxembourg: Publications Office of the European Union; EUR - Scientific and Technical Research Series.

STECF (2016). Assessment of Balance Indicators for Key Fleet Segments and Review of National Reports on Member States Efforts to Achieve Balance between Fleet Capacity and Fishing Opportunities (STECF-16-18). Luxembourg: Publications Office of the European Union; EUR - Scientific and Technical Research Series.

Tsagarakis, K., Coll, M., Giannoulaki, M., Somarakis, S., Papaconstantinou, C., and Machias, A. (2010). Food-web traits of the North Aegean Sea ecosystem (Eastern Mediterranean) and comparison with other Mediterranean ecosystems. Estuar. Coast. Shelf Sci. 88, 233-248. doi: 10.1016/j.ecss.2010.04.007

Tsagarakis, K., Palialexis, A., and Vassilopoulou, V. (2014). Mediterranean fishery discards: review of the existing knowledge. ICES J. Mar. Sci. 71, 1219-1234. doi: 10.1093/icesjms/fst074

Tudela, S. (2000). "Assessment of the ecological footprint of fishing in the Catalan central coast (NE Spain)," in Fishing Down the Mediterranean Food Webs?, CIESM Workshop Series no. 12, ed F. Briand (Kerkyra: CIESM), 79-82.

Tudela, S., Coll, M., and Palomera, I. (2005). Developing an operational reference framework for fisheries management on the basis of a two-dimensional index of ecosystem impact. ICES J. Mar. Sci. 62, 585-591. doi: 10.1016/j.icesjms.2005. 01.008

Vasilakopoulos, P., Maravelias, C. D., and Tserpes, G. (2014). The alarming decline of Mediterranean fish stocks. Curr. Biol. 24, 1643-1648. doi: 10.1016/j.cub.2014.05.070

Walters, C. J., Christensen, V., Martell, S. J., and Kitchell, J. F. (2005). Possible ecosystem impacts of applying MSY policies from single-species assessment. ICES J. Mar. Sci. 62, 558-568. doi: 10.1016/j.icesjms.2004.12.005

Worm, B., and Myers, R. A. (2003). Meta-analysis of cod shrimp interactions reveals top down control in oceanic food webs. Ecology 84, 162-173. doi: 10. 1890/0012-9658(2003)084[0162:MAOCSI]2.0.CO;2

Conflict of Interest Statement: The authors declare that the research was conducted in the absence of any commercial or financial relationships that could be construed as a potential conflict of interest.

Copyright (c) 2017 Colloca, Scarcella and Libralato. This is an open-access article distributed under the terms of the Creative Commons Attribution License (CC BY). The use, distribution or reproduction in other forums is permitted, provided the original author(s) or licensor are credited and that the original publication in this journal is cited, in accordance with accepted academic practice. No use, distribution or reproduction is permitted which does not comply with these terms. 